\title{
Verification of RFID Tags Properties on the Tagged Products
}

\author{
Dušan Dorčák ${ }^{1}$, Romana Hricová ${ }^{2}$, Peter Šebej $^{3}$
}

\begin{abstract}
Technologies of monitoring, registration and identification of goods in production systems are commonly encumbered by various characteristic effects in each industrial production. These effects influence readability of identification tags during their lifecycle (e.g. wear, attrition), which can lead into reduction or loss of functional properties of the technology, which can be critical to traceability. This paper deals with the basic stress test procedures the RFID labels (tags, responders, label, key chains, stickers,...), currently preferred technology of IoT (Internet of Things) along with the basic theoretical part of the framework.
\end{abstract}

Keywords: RFID, label, Internet of Things, functionality, durability, operational reliability

\section{Introduction}

The most of the goods going through the production process are marked, recorded and can contain more types of identification. These marks or tags are used for technological, qualitative and verification purposes. During the production process and manipulation with goods, there are various types of possible deterioration and functional properties reduction of the marks. Therefore it is a serious deficiency if the marks lose their function in the process of their life time.

Nowadays understanding of exact system approach labeling (marking the creation and preservation of relevantly-readable values for the determination of the original, with the need to show the genesis of entities, with the possibility of backward traceability during the entire period of the entities) does not validate mere compliance (picture) with its knowledge of reality, but it verifies the quality and opportunity and exact determination of the original item. The determination of the original means it is made directly or by registration, and also the validity or accuracy of the interpretation of the transmitted information. (In this position, the tagging appends additional skills, abilities, habits of a person, transmitting the information, recording information, store information, etc.).

\footnotetext{
1 Development and Realization Workplace of Raw Materials Extracting and Treatment, Technical University of Kosice, B. Nemcovej 32, 04384 Kosice, Slovakia

e-mail: dusandorcak@gmail.com

2 Department of Manufacturing Management, Faculty of Manufacturing Technologies with a seat in Presov, Technical University of Kosice, Bayerova 1, 08001 Presov, Slovakia

e-mail: romana.hricova@tuke.sk

3 e-mail: sebejt@gmail.com
} 
Each technology should be understood and compared in the particular conditions. RFID tags labeling appears over other technologies in specific cases as large series and single part production, as preferable technology in compare to bar code technology or manual data input. [3,5] The ambitious of the article is to show the basic stress test procedures the RFID labels, because one of the arguments against RFID implementation in the enterprises is high costs. During the testing will be shown that RFID technology is long-lived, tags lifecycle is long what means that risk of the reduction or loss of functional properties of the technology, which can be critical to traceability, is not critical.

\section{Model of RFID tag usage}

An important indicator of usage is the number of loading cycles of simple pressure on the good, which can carry the label. The initial conditions are:

- good is in the warehouse,

- the worker has the good with other pieces ready for next operation step,

- the good production lifecycle is for example 2-30 days,

- the processing ratio of the warehouse and worker is $20 \%$ to $80 \%$,

- the number of parts that processes worker is 5-15,

- the storage column height of the parts is $5-30 \mathrm{~cm}$.

Estimated normal pressure of parts with the same size, registered as medium pressure exerted by the column height of $1 \mathrm{~mm}$ is $0.000764 \mathrm{~g} / \mathrm{mm}^{2}$.

Pressure in the bottom column varies from 0.038216 to $0.229297 \mathrm{~g} / \mathrm{mm}^{2}$ (in our testing we applied a value close to the upper limit $0.209775 \mathrm{~g} / \mathrm{mm}^{2}$ ). It is expected to have good/part at each column or at the bottom of the column. Then consideration should be given to the following pressures:

$0.038216 \mathrm{~g} / \mathrm{mm}^{2}$ pressure at a depth of $50 \mathrm{~mm}$ from the top of the column

$0.191081 \mathrm{~g} / \mathrm{mm}^{2}$ pressure at a depth of $250 \mathrm{~mm}$ from the top of the column

$0.229297 \mathrm{~g} / \mathrm{mm}^{2}$ pressure at a depth of $300 \mathrm{~mm}$ from the top of the column

Worker stores parts usually on top of the column, but the exact part position is random and the average position is approximately in the middle of the column, therefore middle pressure which acts on the label is in the same range.

If the worker routinely works with parts, we can suppose that one or two parts are taken away and given back to the column which can lead into intensive use, can cause higher cycle number (estimated value approximately 14 cycles). These values are higher at comparative process of multiple parts.

Above mentioned estimates show (Table 1), that little active units should get into load cycle in column with the pressure ranged from 0.038 to $0.299 \mathrm{~g} / \mathrm{mm} 2$ of approx. 1000 cycles.

Intensive pieces have predicted number of cycles in a lifetime about 2,6e6, therefore we have to carry out such amount of cycles. To demonstrate this charac- 
teristics (resistance to load tag by nominal pressure), it is appropriate to make these tests more with the expected number of approx. 1e6 to 1e7 load cycles. [3,5]

\section{Types of test cycles}

For our test we selected multiple possible tag positions:

1. longitudinal

2. across

3. on the outside

4. on the in side

Possibility of placement number 3 (on the outside) has been tested as first option. This position has suitable properties to reach good results. Tag can be stressed in various areas. We have considered these three options:

1. Load on whole label surface with an overlap.

2. Load on $2 / 3$ of the label surface (loaded edge passes through the antenna).

3. Load on $1 / 2$ of the label surface (loaded edge passes through the label chip and through contact connection between chip and antenna).

Other ways to load may include:

1. The special alternative pressure loads.

2. Pressure on uneven part surface.

3. Stuck fragment or grain, splint... causing a significant increase of local pressure.

Fig.1 shows Alien 9540 Squiggle label with the image of the antenna and the chip. Fig. 2 shows when parts have the same size and during warehousing the worker puts them nicely at each other practically by whole area. In this case, the label is loaded almost evenly over its whole surface.

During the column stacking of parts with various sizes and formats, the label is not loaded on whole surface. The same situation of partial load of label area is when the same sized parts are stacked incorrect and the loading areas are partially overlapping. From the mentioned situation, repeated load of the $2 / 3$ part of label (Fig.3) and $1 / 2$ part of label was tested (Fig.4).

The nominal pressure was carried out with characteristics similar to the normal parts storage to the column (flow contact speed is ... $0.3 \mathrm{~m} / \mathrm{s}$ ) (similar to the manual stacking) in count cycles proposed above. 


\section{Testing approach}

The tests were accomplished in the conditions as real as possible. The tested unit was cyclic loaded by column storage in the time range of approximately one work shift (6 - 9 hours, depended on staff possibilities). After this stage of cyclic load, followed break till the next working day. Parts column is in the monitoring, testing unit. This phase can be considered as relaxation.

Dynamic loading is finished in this part of testing and can be expected, that any changes in the label are stabilized.

After five days, weekend relaxation phase followed. The model has been applied until completion (estimated, required, needed) the number of cycles. [1,2]

\section{Description of the main categories}

The basic categories include the following:

\section{Reliability}

Product characteristics which determines the guaranteed ability to perform a required function and meet the operational conditions in a given range and time, according to technical conditions, respectively according to contractual requirements.

In fact, these are the following properties: no-failure operation, durability, reliability, maintainability, storability, etc.

\section{No-failure operation}

Product attribute to meet the ongoing functions expected during a specified period of operation and under the required conditions. Numerically, it is expressed as e.g. probability of trouble-free operation in a specified time, the failure rate, a median failure-free operation.

\section{Maintainability}

Product ability consisting of error tolerance and the causes prevention and revitalization incurred faults and damage. It is the ability of removing them capable of maintaining and achieving initial operational status.

\section{Reliability testing}

Is a process by which we determine, measure and manage values of the reliability.

Reduction and acceleration testing of reliability, durability and functionality

Measurement and loading of the chosen pieces carried out under standardized conditions to have information about the product reliability in shorten periods as during the operational conditions which are defined in the technical conditions of the product. Selected special conditions mustn't change the disorders. It is proven 
that in case of electrical products the temperature is an accelerating mechanism which speeds up the tests in compared to normal operating temperature.

Failure rate, median $-\lambda s$

Determination of systems reliability, especially for indicative calculations of reliability, is mean failure rate $-\lambda \mathrm{s}$. This average value of the failure rate (point estimate) of test failure classes of the same type used in technical facilities and technological design. $\lambda \mathrm{s}$ value obtained by credible manner allows a realistic assessment system uptime in a situation, where all factors necessary for a more accurate estimate are not known yet. It is expressed as a ratio of the total number of failures on a specified time for example $\lambda$ [FIT] is 1 Fault in $109 \mathrm{hrs}$.

\section{Mean time between failures - MTBF}

The ratio between the operating times of the repaired product to the expected number of failures during this operating time. The effect of this variable is expressed in time units [hour].

Failures taxonomy

Failures can be divided into:

- catastrophic for which component or product fails to perform its function (irreparable)

- degradation, in which the components, product changes parameters, but can continue to operate with the changed parameters. [4, 12]

\section{A description of the theoretical basis of testing}

Time shortened (accelerated) test functionality (reliability) allow to obtain reliable and comparable values of reliability for significantly less time with a smaller set of products as if they were obtained under standardized conditions during normal operation (expensive and long-term measurements with a large number of samples with not-guaranteed completion).

Most of the tested and integrated entities and integrated have under normal operating conditions, very long technical life (usually 108 to 1,012 hours of operation, 105 to 1014 mechanical cycles).

From above mentioned technical life outcomes the intensity of component failures in the range of 10-8 to 10-12 hours. Under these conditions, the overall mean time between labels failures is millions of operating hours. Failure rate for parts or appliances at $\mathrm{T} 2$ temperature is:

$$
\lambda(T)=A \cdot e^{E a_{1} \cdot z}+(1-A) \cdot e^{E a_{2} \cdot z}
$$

at which:

$$
z=\frac{1}{k}\left(\frac{1}{T_{\text {amb,ref }}}-\frac{1}{T_{2}}\right)
$$

, where: 
A is a component's parameter, $E_{a 1}, E_{a 2}$ are the activation energy $[\mathrm{eV}]$ and $\mathrm{k}$ is Boltzmann constant $\mathrm{k}=\mathrm{eV} 8,618.10-5^{\circ} \mathrm{K}$, $\mathrm{T}_{\mathrm{amb}, \mathrm{ref}}=313^{\circ} \mathrm{K}$ is the reference ambient temperature $\left(273^{\circ}\right.$ to $\left.+40^{\circ} \mathrm{C}\right)$. $\mathrm{T} 2$ is temperature $\left[{ }^{\circ} \mathrm{K}\right]$.

To verify such reliability parameter by conventional procedure, enormous amount of products would be required- electronic meters (several hundred pieces), even though tests would take several thousands of hours.

Therefore, the only acceptable method of reliability parameters verification of the final products is carried out by laboratory accelerated reliability tests. During the shortened tests of reliability it is necessary to determine the mechanism, calculate the accelerating factor and corresponding numerical value of acceleration of the individual components making up the final product - label.

In case of electronic products is clearly demonstrated that the accelerating mechanism is higher temperature $\left(100^{\circ} \mathrm{C}\right)$ in which accelerating tests are performed compared to normal operating temperature (e.g. $23^{\circ} \mathrm{C}$ ). Other possible accelerating effects such as dependence on the operating voltage and the operating current dependence are not feasible for tested electronic systems.

The shortening (accelerating) factor ranges from 1 for the mechanical parts on which incensement of operating temperature has no effect (plugs, soldered points, etc.) up to 100 - for very sensitive components to operating temperature (electrolytic capacitors optical components, etc.). If we put to the equation (1) $\mathrm{A}=1, \mathrm{E}_{\mathrm{a} 2}$ $=0$, this model is equal to the Arrhenius equation. The accelerating factor $\pi \mathrm{T}$ according to the test temperature $\left(100^{\circ} \mathrm{C}\right)$ and the normal operating temperature $\left(23^{\circ} \mathrm{C}\right)$ can be calculated by use of above mentioned Arrhenius equation:

$$
\lambda(T)=e^{E a_{1} \cdot z}
$$

accelerating factor is defined as:

$$
\pi_{T}=\frac{\lambda}{\lambda_{\text {ref }}}
$$

, where:

$\lambda_{\text {ref }}$ is the failure rate at reference conditions.

$\pi_{\mathrm{T}}$ is a factor depending on the temperature (an accelerating factor)

This method is an internationally standardized and described in [1]. 


\section{Determination of temperature dependency value $\pi_{\mathrm{T}}$ and failure product rates $\lambda s$}

To increase the accuracy to calculate $\pi_{\mathrm{T}}$ empirical model describing the failure rate dependence on temperature can be used [5]. Two activation energies are used in order to include also cases, when during the malfunction process dominate two or more mechanisms.

$$
\begin{aligned}
& \pi_{T}=\frac{A \cdot e^{E a_{1} \cdot z}+(1-A) \cdot e^{E a_{2} \cdot z}}{A \cdot e^{E a_{1} \cdot z_{r e f}}+(1-A) \cdot e^{E a_{2} \cdot z_{r e f}}}(5 \mathrm{a}) \\
& z=\frac{1}{k}\left(\frac{1}{T_{a m b, r e f}}-\frac{1}{T_{2}}\right) a z_{r e f}=\frac{1}{k}\left(\frac{1}{T_{a m b, r e f}}-\frac{1}{T_{1}}\right)
\end{aligned}
$$

Used symbols:

$$
\begin{array}{cl}
\mathrm{A} & \begin{array}{l}
\text { constant } \\
E_{a 1}, E_{a 2}
\end{array} \\
\mathrm{k} & \begin{array}{l}
\text { activation energy }[\mathrm{eV}] \\
\text { the Boltzmann constant } \mathrm{k}=\mathrm{eV} 8,618.10-5 \mathrm{eV}^{\circ} \mathrm{K}
\end{array} \\
T_{a m b, r e f} & \\
\left.\mathrm{C}+40{ }^{\circ} \mathrm{C}\right) & \text { reference temperature }\left[{ }^{\circ} \mathrm{C}\right] \\
\mathrm{T}_{1} & \text { temperature }\left[{ }^{\circ} \mathrm{K}\right] \\
\mathrm{T}_{2} & \text { reference temperature }\left[{ }^{\circ} \mathrm{C}\right] \\
\mathrm{t}_{1} & \text { temperature }\left[{ }^{\circ} \mathrm{C}\right] \\
\mathrm{t}_{2} &
\end{array}
$$

Based on the initial value (measured or calculated) $\lambda$ values and calculated factor of depended on the temperature $\pi_{T}$, can be determined $\lambda_{\text {ref }}$ according to the above mentioned dependencies:

$$
\lambda_{\text {ref }}=\frac{\lambda}{\pi_{T}}
$$

\section{Interpretation of shortened tests}

Test interpretation is according to STN IEC 60605-4. Constant failure intensity is assumed.

Used symbols:

$\mathrm{T}^{*}[\mathrm{~h}] \quad$ accumulated less time testing in applicable test point

$\mathrm{t}[\mathrm{h}] \quad$ test time 
$\chi_{\mathrm{p}}^{2}(v) \quad$ theoretical value of $\mathrm{p}$-quantile distribution $\chi^{2} \mathrm{~s}$ with degrees of freedom

$\mathrm{r} \quad$ the count of failures

$\mathrm{n} \quad$ the count of electrometers

$\chi_{0,95}^{2}\left(2 r_{0}\right) \quad$ p-quantile distribution at $90 \%$ significance level and degrees of freedom 2 ro

a) Cumulative valid time test

$$
T^{*}=\sum_{m=1}^{n} t m \quad(7)
$$

, where

$\mathrm{t}_{\mathrm{m}}$ is measured less time testing $\mathrm{m}$-th product at the relevant time

b) Point estimate of mean time between failures MTBF

$$
M T B F=\frac{T^{*}}{r}, \text { for } \mathrm{r} \geq 1, \quad M T B F=3 \cdot T^{*}, \text { for } \mathrm{r}=0(8)
$$

c) upper $m_{h}$ and lower $m_{d}$ significance levels mean time to failure at a significance level of $90 \%$

$$
m_{d}=\frac{2 \cdot T^{*}}{\chi_{0,95}^{2}(2 r+2)} \quad m_{h}=\frac{2 \cdot T^{*}}{\chi_{0,05}^{2}(2 r)}
$$

If no error occurs during the tests (suitable for a small number of defects), the lower limit levels of significance have to be determined as:

$$
m_{d}=\frac{2 \cdot T^{*}}{\chi_{0,90}^{2}(2 r+2)}(10)
$$

values $\chi_{\mathrm{p}}^{2}(v)$ shall be determined from Table 2 STN IEC 60605-4. [6]

d) Validity test assuming constant failure rate.

The test can be performed if the number of faults is greater than 3 . For the number of failures less than 3 , the assumption constant failure rate adopted without testing is true.

- appointed cumulative valid test time $T_{k}$, for $k=1,2, \ldots, r$

$$
T_{k}=\sum_{m=1}^{n} t_{k, m}(11)
$$

, where

$\mathrm{t}_{k, m}$ is measured valid time testing of the product number in the $\mathrm{m}$-th failure

- value (quantile) of test statistic is calculated

$$
\chi^{2}=2 \times \sum_{k=1}^{r} \ln \left[\frac{T^{*}}{T_{k}}\right] \text { (12) }
$$

- from the table 1 STN IEC 60605-6 are count off $\chi_{0,05}^{2}(2 r)$ a $\chi_{0,95}^{2}(2 r)$, - assumption of a constant flow of failures is confirmed, if true is 


$$
\chi_{0,05}^{2}(2 r) \leq \chi^{2} \leq \chi_{0,95}^{2}(2 r)(13)
$$

\section{Implementation of shorter reliability tests and determination of failure rate components $\lambda s$}

Seemingly separate part is the practical testing stage of product reliability. It is time-consuming and very costly, but necessary, because only after practical verification of the results we can (with a certain probability) prejudge products reliability.

There is a general opinion that ensures objectivity respectively the reason for accepting the results of accelerated tests of reliability by customers, which is that there should be an independent organization as sponsor of accelerated tests. [7, 13]

Based on the above documentation and the applicable international standards, it is possible for the exercise of reliability abbreviated laboratory tests to determine the intensity of these disorders.

Measurements in RFID laboratory show, that during 234241 load cycles, when measured labels were being stored in a stack, no label lost its function.

\section{Conclusions}

Independent source of information about products which are based on observed traffic and we obtain thanks to application of shorten measurements in normal operating practice at reasonable cost and times. Most of direct and indirect benefits in the areas of management, monitoring and improving the quality of products as well as manufacturing processes and technologies are brought as well.

Not excluding from the data set information on the actual extrapolated functionality as well as their quality and effectiveness of involvement in the process. These characteristics of truncated measurements and the benefits can be recommended to any production. It also has the potential to improve the overall economical and qualitative effect.

\section{References}

[1] Klas, A.: Identifikácia predpokladov a možností prekonávania technologickej a inovačnej medzery SR, Bratislava : Ústav slovenskej a svetovej ekonomiky SAV , 2005 
[2] Finkenzeller, K.: RFID Handbuch, 4-te Auflage, Hanser Verlag, Mníchov 2006, ISBN 3-446-40398-1

[3] http://193.87.95.91/phpbb3/download/file.php?id=3045

[4] Klementev, I. - Kyška, R.: Elektrické meranie mechanických veličín., Bratislava, Vydavatel'stvo Alfa, 1990

[5] Šebej. Р.: Проверка надежности, (долговеренности, долговечности) електронных оборудовании, The Test of Reliability, Zborník: BAV, ROBCON-4, Sofia 1987. Svante August Arrhenius

[6] Strelec S.: Vplyv fyzikálnych faktorov na spol'ahlivost' RFID technológie, Prešov : FVT TUKE, 2009

[7] Want, Roy,: RFID Explained, USA, 2006 : Morgan and Claypool Publishers, ISBN 978-1-59829-108-7

[8] Modrák,V., Knuth, P., Šebej, P.: Adoption of RFID in warehouse management. In: Centeris 2010 conference, Proceedings: 20-22 October 2010, Portugal

[9] Modrák, V., Knuth, P., Novak-Marcincin, J.: Advantages and risks of RFID in business applications. International business management 4 (1), pp. 28-34 (2010)

[10] Knuth, P., Šebej, P : Overovanie vlastností RFID štítkov na označovaných predmetoch (2010). In: DoNT 2010 : Day of New Technologies : zborník príspevkov a prednášok $\mathrm{z}$ vedeckej konferencie $\mathrm{s}$ medzinárodnou účast'ou : 19.11.2010, Žilina. Žilina : EDIS Vydavatel'stvo ŽU, 2010 S. 74-87. - ISBN 978-80-554-0279-6

[11] Knuth, P., Šebej, P, Zagora, M.: Strata efektívnosti identifikačných a evidenčných technológií (2010). In: DoNT 2010 : Day of New Technologies : zborník príspevkov a prednášok z vedeckej konferencie s medzinárodnou účast’ou : 19.11.2010, Žilina. Žilina : EDIS Vydavatel'stvo ŽU, 2010 S. 88 - 95. - ISBN 978-80-554-0279-6

[12] Balog, M., Husár, J.: Methodical framework of flexibility production evaluation in terms of manufacturing plant, In: Key Engineering Materials : Operation and Diagnostics of Machines and Production Systems Operational States 3. Vol. 669 (2016), p. 568577. - ISBN 978-3-03835-629-5 - ISSN 1662-9795

[13] Balog, M., Szilagyi, E., Mindas, M.: Utilization of RFID Technology for Monitoring Technical State of Chosen Elements of Cargo Railway Wagon, In: International Journal of Engineering Research in Africa. Vol. 18 (2015), p. 167-174. - ISSN 1663-3571. 
Table 1 Estimated number of loading RFID tag cycles necessary for the test [authors]

\begin{tabular}{|l|l|l|l|}
\hline & $\begin{array}{l}\text { Mini- } \\
\text { mum }\end{array}$ & $\begin{array}{l}\text { Maxi- } \\
\text { mum }\end{array}$ & Unit \\
\hline Production lifecycle & 2 & 30 & day \\
\hline The processing time ratio workers & 0,2 & 0,8 & $\begin{array}{l}\% / 10 \\
0\end{array}$ \\
\hline The number of pieces at each worker & 5 & 15 & piece \\
\hline Column height & 50 & 300 & $\mathrm{~mm}$ \\
\hline Pressure on the tag (RFID tag) & 0,038 & 0,229 & $\begin{array}{l}\mathrm{g} / \mathrm{mm} \\
2\end{array}$ \\
\hline The number of cycles by worker & 3 & 18 & $\mathrm{c} / 1$ \\
\hline $\begin{array}{l}\text { Estimation of potential cycles with an expected life- } \\
\text { time }\end{array}$ & 1095,75 & 262980 & $\mathrm{c} / 1$ \\
\hline
\end{tabular}

Figure 1. Picture of Alien 9540 Squiggle label with the image of the antenna and the chip [authors]

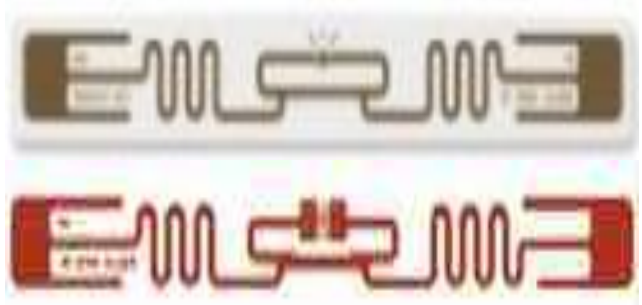

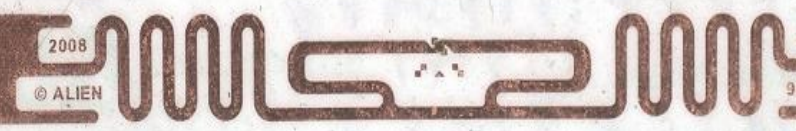

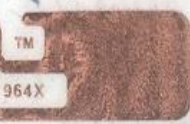

Figure 2. Picture of whole label load evenly by rated pressure [authors]

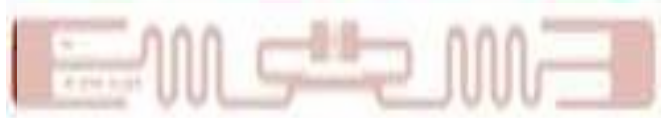


Figure 3. Picture of $2 / 3$ label load with nominal pressure [authors]

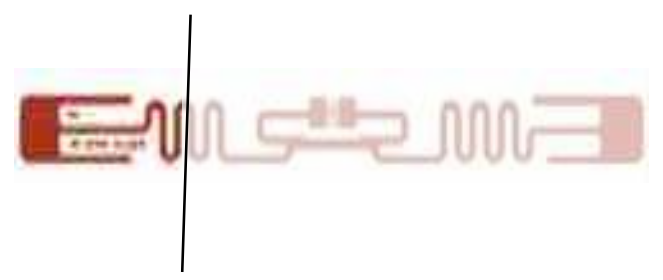

Figure 4. Picture of 1/2 label load with nominal pressure [authors]

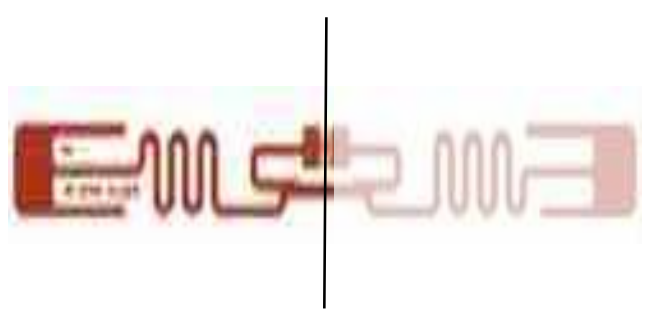

